\title{
Rola nadzoru spawalniczego w pracach remontowych konstrukcji przemysłowych
}

\author{
The role of welding supervision in the repair \\ of industrial structeres
}

\section{Streszczenie}

W artykule przedstawiono główne zadania i rolę nadzoru spawalniczego podczas prac remontowych konstrukcji przemysłowych. Ich zakres opisano w oparciu o doświadczenia autora w zakresie wykonywania nadzorów nad pracami związanymi z wymianą carg cementowego pieca obrotowego. Zwrócono również uwagę na specyficzne problemy występujące podczas prowadzenia prac naprawczych, dotyczące np. doboru spawaczy i weryfikacji ich uprawnień, zapewniania właściwych warunków środowiskowych do prowadzenia prac spawalniczych, weryfikacji poprawności przygotowania złączy do spawania oraz bieżącej kontroli jakości wykonywanych spoin.

Słowa kluczowe: nadzór spawalniczy; prace remontowe; spawane konstrukcje stalowe

\begin{abstract}
The article presents the main tasks and the role of welding supervision during the repair works of industrial constructions. The scope is described on the basis of the author's experience in supervising the work of replacement the girdles of concrete rotate kiln. Furthermore, it shows the specific issues encountered during the repair works regarding: selection of welders and verification of their qualifications, the assurance of appropriate environmental conditions for welding work, verification of the preparation of welding joints and the ongoing quality control of welds.
\end{abstract}

Keywords: welding supervision; repair works; welded steel structures

\section{Wstęp}

Rola nadzoru spawalniczego, podczas wykonywania prac remontowych konstrukcji przemysłowych, jest ważną i odpowiedzialną funkcją, aczkolwiek często niedocenianą. Nadzór spawalniczy jest odpowiedzialny między innymi za opracowanie procedur i instrukcji niezbędnych do wykonania prac, dobór sprzętu i technologii spawania. Powinien również przeprowadzić weryfikację umiejętności spawaczy oraz nadzór nad wykonywaniem prac spawalniczych. Pełny zakres obowiązków nadzoru określany jest zgodnie z zapisami w normie PN-EN ISO 14731 [1]. Prace w zakresie remontów prowadzone są najczęściej w oparciu o wymagania PN-EN ISO 3834-2 [2].

W zależności od zakresu prac, pracownicy nadzoru powinni posiadać odpowiednią wiedzę oraz kompetencje:

- przy wykonywaniu napraw prostych konstrukcji spawanych personel powinien posiadać podstawową wiedzę techniczną (Międzynarodowy Mistrz Spawalnik (IWS)) [3];

- jeżeli prace spawalnicze prowadzone są w ograniczonym zakresie technicznym lub wybranym jego zakresie, personel nadzoru powinien posiadać specjalną wiedzę techniczną (Międzynarodowy Technolog Spawalnik (IWT)) [4];
- do planowania, wykonywania oraz prowadzenia nadzoru w pełnym zakresie odpowiedzialności niezbędna jest pełna wiedza techniczna (Międzynarodowy Inżynier Spawalnik (IWE)) [5].

W artykule przedstawiono rolę nadzoru spawalniczego na przykładzie prac remontowych cementowego pieca obrotowego.

\section{Rola nadzoru w pracach przygotowawczych}

Rola spawalnika w zakresie remontów konstrukcji przemysłowych (cementowego pieca obrotowego) powinna zaczynać się na etapie przeglądu wymagań, gdzie podejmowane są decyzje o możliwościach spełnienia, stawianych przez inwestora, wymagań.

Trzeba ocenić czy posiadane zaplecze sprzętowe, ilość oraz rodzaj posiadanego osprzętu i urządzeń spawalniczych, jak i ich sprawność, jest wystarczające do wykonania

Mgr inż. Jakub Kozłowski - Politechnika Częstochowska.

Autor korespondencyjny/Corresponding author: kuba.kozlowski@o2.pl 
zleconego zakresu prac. W tym zakresie nadzór spawalniczy wraz z kierownictwem budowy musi dokonać weryfikacji zasobów sprzętowych w odniesieniu do założonej technologii robót. Musi również zostać zweryfikowana ilość dostępnych pracowników, o odpowiednich kwalifikacjach oraz określonych umiejętnościach i doświadczeniu, niezbędnych do wykonania napraw w ustalonym terminie. Szczególnie należy zwrócić uwagę na odpowiednią liczbę spawaczy. Jeżeli okaże się, że jest ona za mała, wówczas należy podjąć decyzję o ewentualnym podzieleniu części prac lub wynajęciu dodatkowych spawaczy. Istotna jest również weryfikacja uprawnień spawaczy oraz ich praktycznych umiejętności spawania.

Do zakresu prac nadzoru spawalniczego należy również opracowanie niezbędnej dokumentacji spawalniczej. Opracować należy między innymi instrukcję wykonywania prac, z uwzględnieniem wymagań zleceniodawcy oraz innych prac remontowych prowadzonych równocześnie z pracami spawalniczymi np. układanie wymurówki w innym fragmencie pieca, co wiąże się z potrzebą okresowego obrotu pieca. Dążyć należy wówczas, aby harmonogram postępu prac spawalniczych i związana z nimi potrzeba obrotów pieca pokrywała się czasowo z podobnymi wymaganiami prac wymurówkowych. Taka synchronizacja pozwala na zaoszczędzenie czasu, który w pracach remontowych pieca jest bardzo ważnym elementem.

Instrukcja prowadzenia prac powinna zawierać między innymi:

- specyfikację materiału podstawowego;

- wymagania dotyczące jakości wykonanych złączy;

- kolejność układania spoin począwszy od sczepiania po ułożenie lica;

- temperaturę podgrzewania wstępnego i temperaturę międzyściegową;

- rodzaj i ilość zastosowanego sprzętu (źródła prądu, oprzyrządowanie pomocnicze);

- warunki środowiskowe, przy jakich można prowadzić prace spawalnicze;

- rodzaj i gatunki materiałów dodatkowych do spawania oraz warunki ich przechowywania;

- instrukcje technologiczne spawania WPS.

Wraz z instrukcją prac należy przygotować instrukcje technologiczne spawania WPS uwzględniające wszystkie zmienne istotne dla danego procesu pozwalające na wykonanie właściwych złączy spawanych. Fragment przykładowej instrukcji technologicznej spawania WPS, przedstawiającej geometrię rowka spawalniczego oraz kolejność spawania pokazano na rysunku 1.

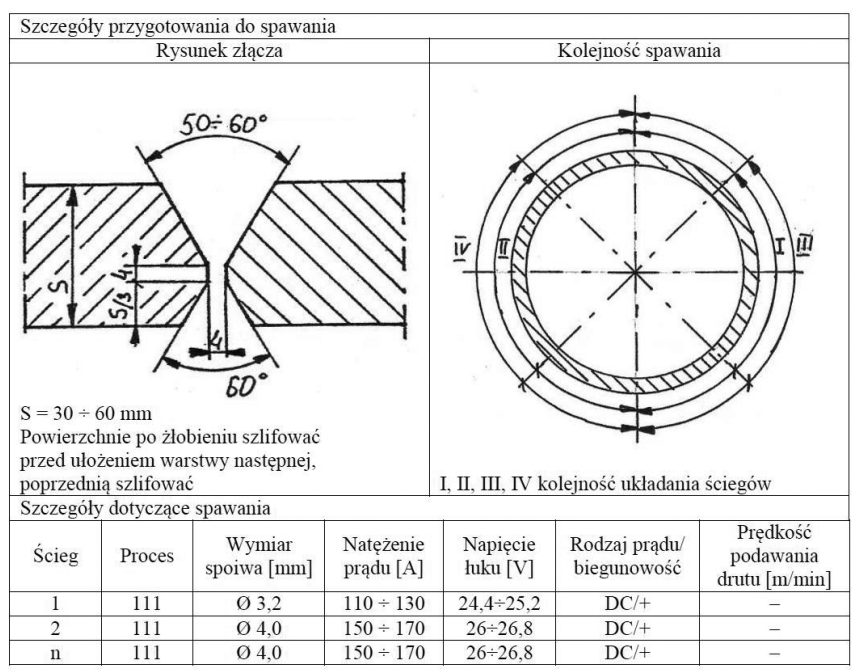

Rys. 1. Fragment instrukcji technologicznej spawania WPS Fig. 1. Part of Welding Procedure Specification
Wymagane również przez inwestora jest opracowanie dziennika spawania dla dokumentowania prac spawalniczych.

Z opracowanymi dokumentami spawalnik zobowiązany jest zapoznać nadzór budowy - kierownika, mistrza oraz brygadzistów. Szczególną uwagę należy zwrócić na przekazanie wymagań w zakresie spawania spawaczom oraz pracownikom wykonującym prace przygotowawcze (przygotowanie złącza, żłobienie grani, zapewnienie właściwego podgrzewania elementów spawanych itp.). Doświadczenie z przeprowadzonych nadzorów pokazuje, że wskazane jest okresowe przypominanie pracownikom wymienionych wymagań.

\section{Weryfikacja uprawnień spawaczy}

Oczywistym jest, że przed dopuszczeniem spawaczy do prac spawalniczych konieczna jest weryfikacja ich uprawnień pod względem ważności i adekwatności do zakresu wykonywanych prac remontowych. Zdarza się, że podwykonawcy delegują do pracy spawaczy, którzy nie posiadają odpowiednich uprawnień lub uprawnienia, jakie posiadają, straciły swoją ważność.

Rolą nadzoru spawalniczego jest dokładna weryfikacja uprawnień, a w razie potrzeby skierowanie spawacza na szkolenie uzupełniające.

Inny ważnym elementem jest sprawdzenie umiejętności spawaczy w zakresie wykonywania złączy analogicznych do zakresu prac. I tu często natrafiamy na duże rozbieżności pomiędzy posiadanymi przez spawaczy uprawnieniami a umiejętnością prawidłowego wykonania złączy. Bardzo często spawacze nie mają wiedzy, co do zakresu posiadanych przez siebie uprawnień.

Podczas weryfikacji spawacza, powinien on wykonać złącze jak najbardziej zbliżone do tych, które mają być wykonywane na konstrukcji. Do tego można wykorzystać materiał z fragmentu konstrukcji, przeznaczonej do złomowania. Po wykonaniu, próbki należy poddać je badaniom wizualnym (VT), penetracyjnym (PT), a następnie ultradźwiękowym (UT) zgodnie z odpowiednimi normami przedmiotowymi. Dodatkowo wykonane próbki należy poddać badaniom niszczącym (próbie rozciągania oraz zginania). Po wykonaniu próby na zginanie boczne można bardzo szybko zweryfikować jakość wykonanego złącza oraz praktyczne umiejętności spawacza. Na rysunku 2 przedstawiono próbki poddane próbie zginania bocznego, gdzie na rysunku 2a przedstawiono poprawnie wykonane złącze próbne (brak defektów na powierzchni rozciąganej), a na rysunku $2 b$ złącze $z$ niezgodnością spawalniczą typu brak przetopu (widoczne naderwanie powierzchni rozciąganej).
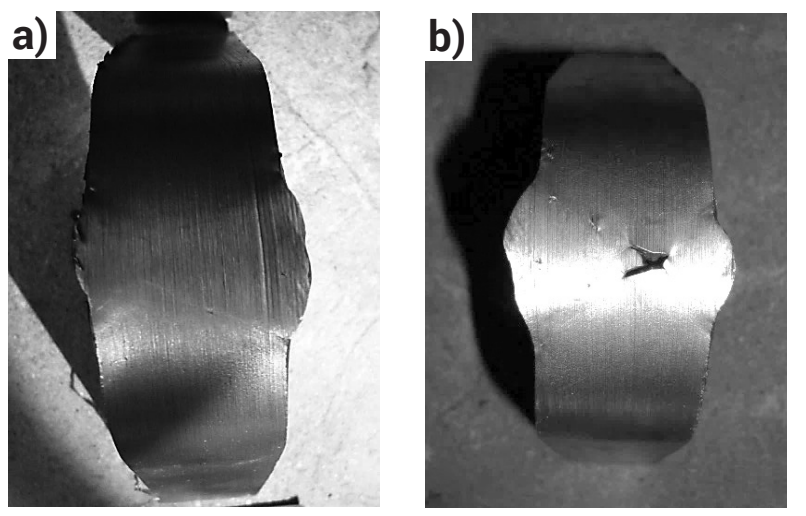

Rys. 2. Widok próbek po próbie zginania bocznego: a) próbka z wynikiem pozytywnym, b) próbka z wynikiem negatywnym

Fig. 2. View of samples after side bend test: a) positive sample b) sample with negative result 
Jak wykazują wyniki badań, znaczna część spawaczy nie zawsze potrafi poradzić sobie z wykonaniem złącza próbnego o wymaganym poziomie jakości. Jako kryterium akceptacji przyjęto poziom jakości „B” wg PN-EN ISO 5817 [7]. Przeprowadzone próby gięcia w niepodważalny sposób ujawniają braki w umiejętnościach spawaczy (rys. 2b). Do prac spawalniczych dopuszczani mogą być jedynie spawacze po uzyskaniu pozytywnych wyników weryfikacji (rys. 2a).

Nadzór spawalniczy musi dołożyć wszelkich starań, aby etap weryfikacji nie zakłócił ciągłości prac remontowych. Niestety przy braku dostępności dostatecznej ilości spawaczy nie zawsze jest to zadanie łatwe do spełnienia.

\section{Nadzór podczas prowadzenia prac spawalniczych}

Podczas prac remontowych nadzór spawalniczy zobligowany jest do kontroli przebiegu prac. Ogromne znaczenia ma przygotowanie geometrii rowka spawalniczego (poprzez ukosowanie krawędzi). Do wykonania pomiarów poprawności ukosowania krawędzi niezbędne są odpowiednie przyrządy np. pięciofunkcyjny spoinomierz (rys. 3).

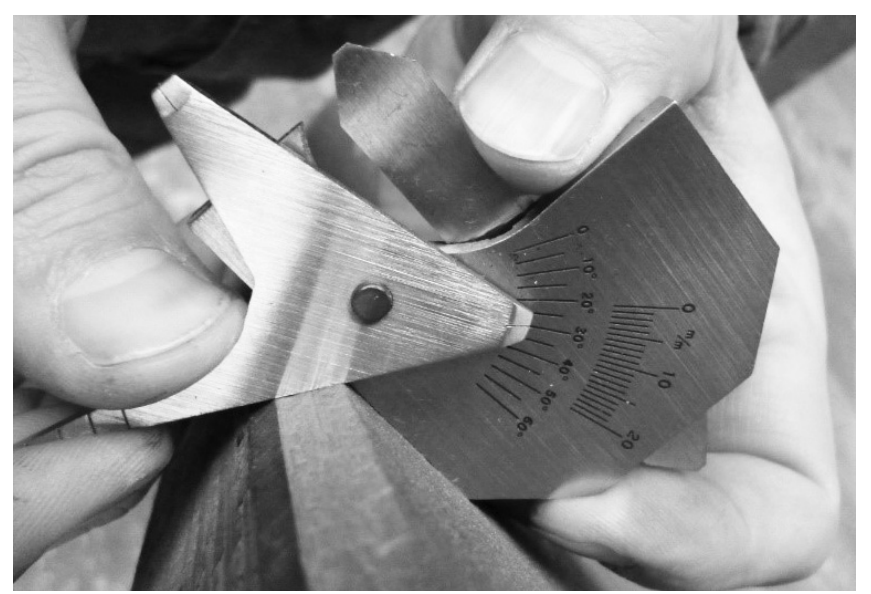

Rys. 3. Sprawdzenie poprawności ukosowania krawędzi Fig. 3. Validation of the bevel edge

Kolejnym ważnym elementem jest prawidłowe pozycjonowanie i unieruchomienie elementów za pomocą odpowiedniego oprzyrządowania np. ścisków i klamr dystansujących (rys.4). Poprawnie wykonanie tych czynności ułatwia pracę spawaczom i może zapobiegać powstawaniu niezgodności spawalniczych.

Temperatura podgrzewania wstępnego to zmienna mająca istotnie wpływać na właściwości złączy spawanych. W przypadku spawania elementów w niesprzyjających warunkach (np. spadek temperatury, zwiększona wilgotność) jej stosowanie musi być bezwzględnie przestrzegane.

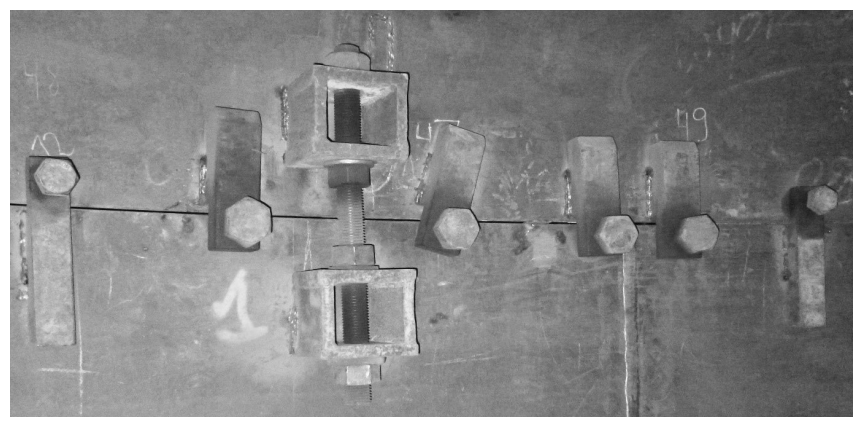

Rys. 4. Przygotowanie elementów do spawania

Fig. 4. Preparation of the component to be welded
Nie zawsze jednak spawacze utrzymują ją na odpowiednim poziomie. Dlatego wskazana jest inspekcja polegająca na wykonaniu przy nich próbnego pomiaru, a następnie poinformowaniu czy zmierzona temperatura jest odpowiednia. W przypadku rozbieżności należy zalecić stosowanie się do wcześniej ustalonych wytycznych. Na rysunku 5 przedstawiono przykład kontroli temperatury podgrzewania wstępnego.

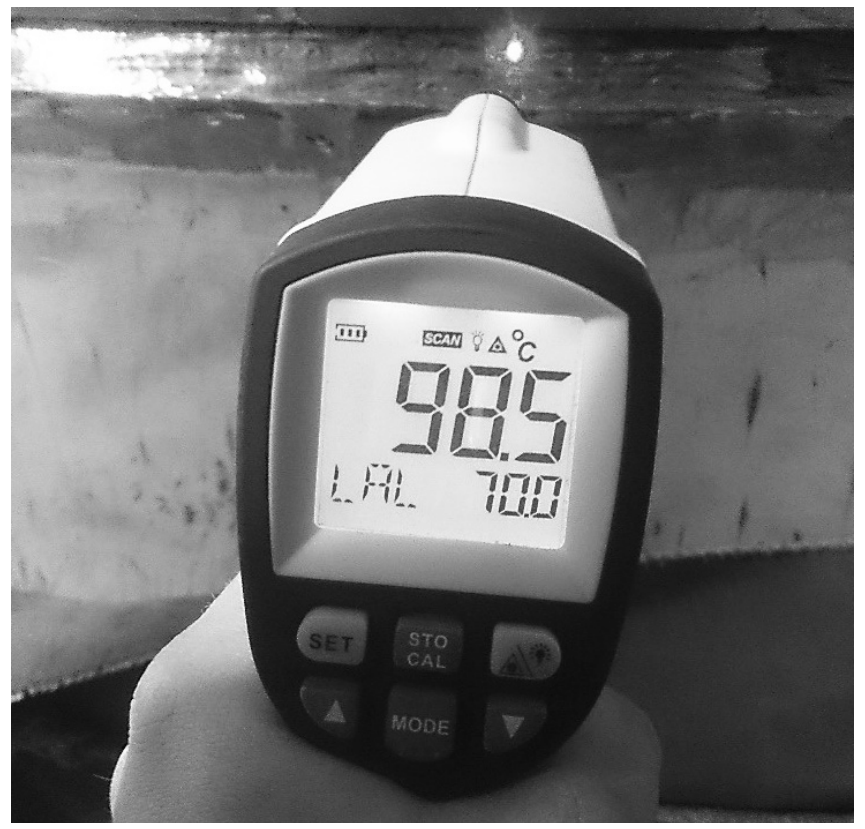

Rys. 5. Kontrola temperatury podgrzewania wstępnego Fig. 5. Preheating temperature control

Osoba nadzorująca wykonywanie prac spawalniczych powinna zwracać szczególną uwagę na prawidłowe przechowywanie materiałów dodatkowych. W przypadku elektrod otulonych: czy są odpowiednio przetrzymywane i suszone (np. zgodnie z zaleceniami producenta), czy w miejscu wykonywania prac pracownicy korzystają ze specjalnie przygotowanych termosów (rys. 6). Jeżeli elektrody są niewłaściwie przechowywane to ich użycie do spawania, może prowadzić do formowania się niezgodności spawalniczych, co w konsekwencji spowoduje konieczność naprawy wykonanej spoiny i narazi na dodatkowy koszt oraz opóźnienie w pracach, gdzie przy napiętych grafikach remontu może opóźnić to planowane zakończenie całkowitego remontu.

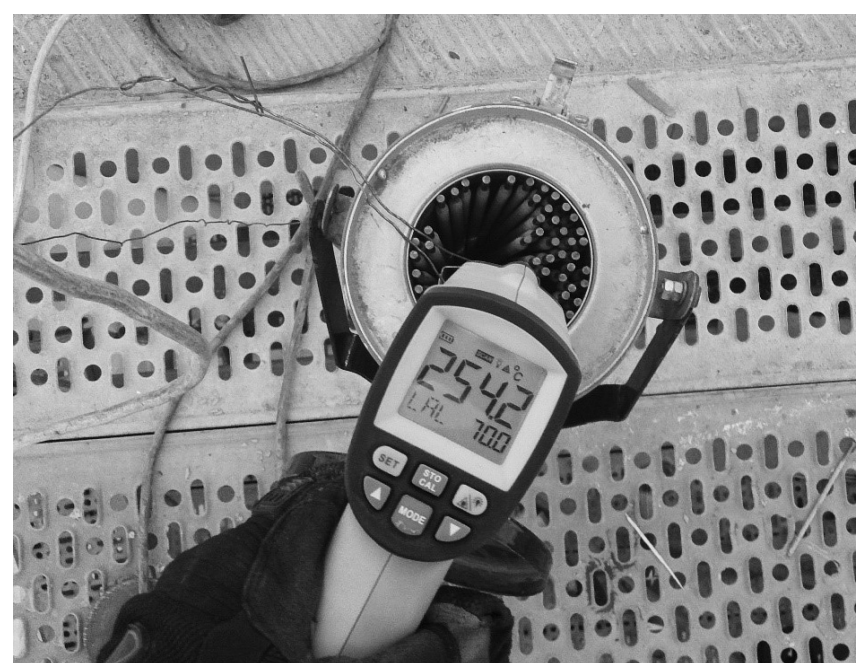

Rys. 6. Materiały dodatkowe przechowywane w podgrzewanych termosach

Fig. 6. Filler materials stored in a heated thermos 


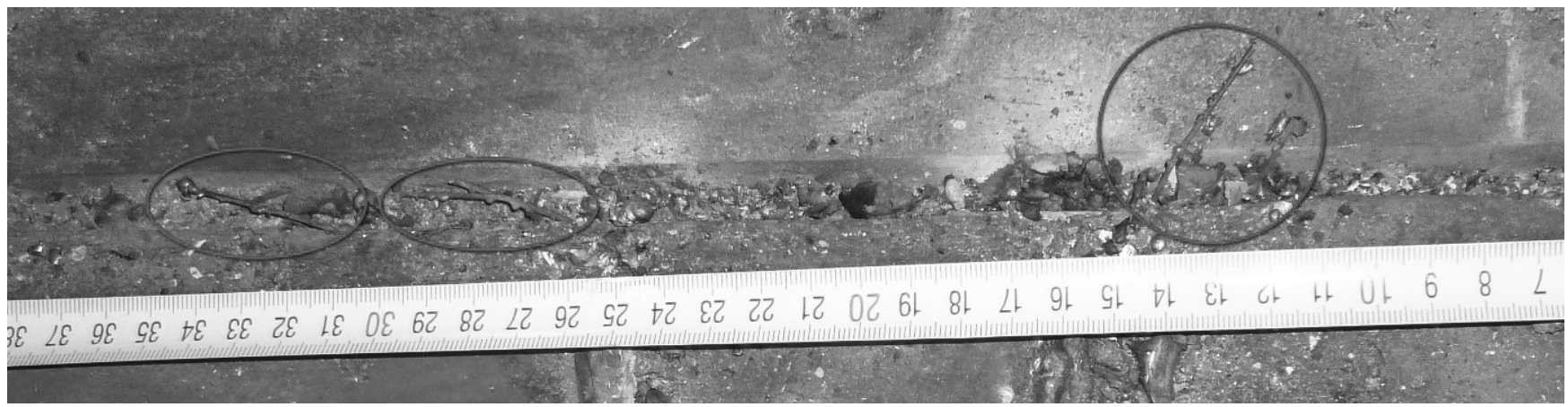

Rys. 7. Niepoprawnie wykonana warstwa przetopowa

Fig. 7. Root with welding imperfection, part of filler material (solid wire)

Podczas rozpoczynania prac spawalniczych należy zachować szczególną ostrożność przy wykonywaniu ściegu przetopowego. Jeżeli spawacze nie wykonają poprawnie warstwy przetopowej i nie zostanie to w porę zauważone, to powstałe niezgodności ujawnią się dopiero podczas badania odbiorczego. Oznacza to, że trzeba będzie usunąć spoinę w miejscu wykrycia niezgodności i wykonać ponownie proces spawania. Na rysunku 7. przedstawiono fragmenty drutu elektrodowego pozostawionego w warstwie przetopowej.

Podczas układania kolejnych warstw konieczne jest odpowiednie czyszczenie, np. poprzez wyszlifowanie warstwy poprzedniej, co przedstawiono na rysunkach 8 i 9. Dobrze jest przeszkolić osoby przygotowujące miejsce do położenia kolejnej warstwy (szlifierzy) z zasad przeprowadzania badań metodą penetracyjną (PT) (rys. 10). Dzięki temu przed przystąpieniem do spawania mogą przeprowadzić szybkie badanie penetracyjne i sami będą mogli ocenić czy podłoże jest poprawnie przygotowane.

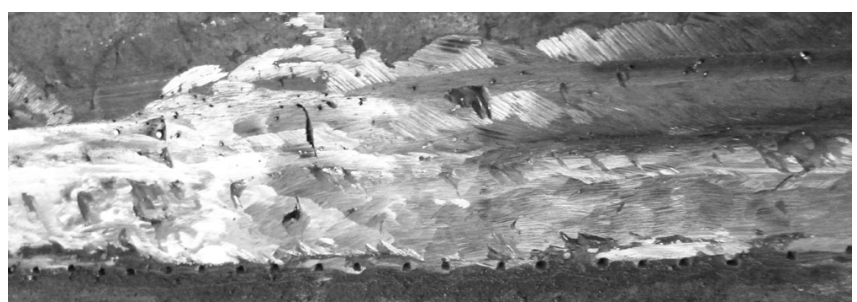

Rys. 8. Źle wykonane przygotowanie przed spawaniem Fig. 8. Wrong made preparation before welding

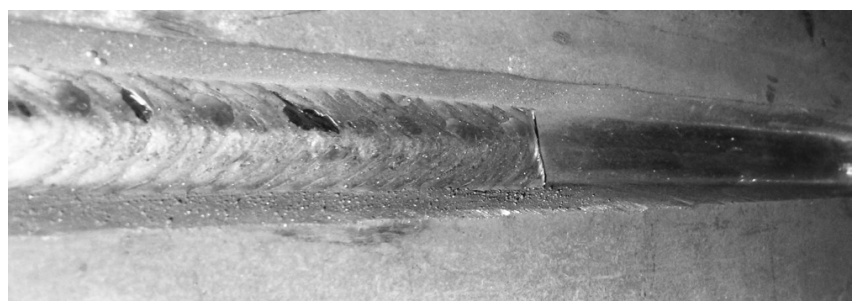

Rys. 9. Poprawne szlifowanie oraz ułożenie kolejnej warstwy Fig. 9. Correct grinding and laying another layer
Ułatwia to pracę samym spawaczom, ponieważ zmniejsza to ryzyko powstania przyklejeń międzywarstwowych lub innych niezgodności wewnętrznych oraz pozwala uniknąć konieczności wykonywania poprawek. Może zdarzyć się, że spawacze nie zauważają lub co gorsze chcąc ułatwić sobie pracę ukrywają niezgodności powstałe podczas spawania wcześniejszej warstwy.

Zalecane jest, aby personel nadzorujący posiadał wiedzę z zakresu badań NDT. Dzięki temu może szybko wykryć powstałe nieciągłości oraz po przeprowadzeniu badań może podjąć decyzję nie czekając na badania wykonywane przez komórki kontroli jakości (rys. 11, 12).

Podczas przeprowadzania remontu wskazane jest, aby osoba prowadząca nadzór nad pracami spawalniczymi regularnie prowadziła badania wizualne wykonywanych złączy, a w razie potrzeby przeprowadzała badania penetracyjne lub magnetyczno-proszkowe. Wskazane jest również prowadzenie aktualnych zapisów postępu prac, występujących problemów i sposobów ich naprawy, jak i oznaczanie spoin wykonanych przez spawaczy.

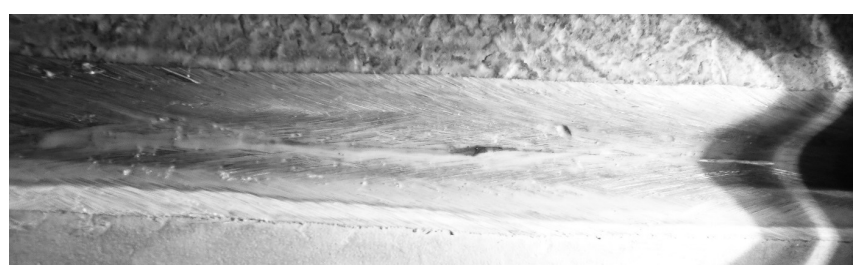

Rys. 11. Ujawnienie nieciągłości przy wykorzystaniu badań penetracyjnych PT

Fig. 11. Disclosure of discontinuities using penetration tests PT

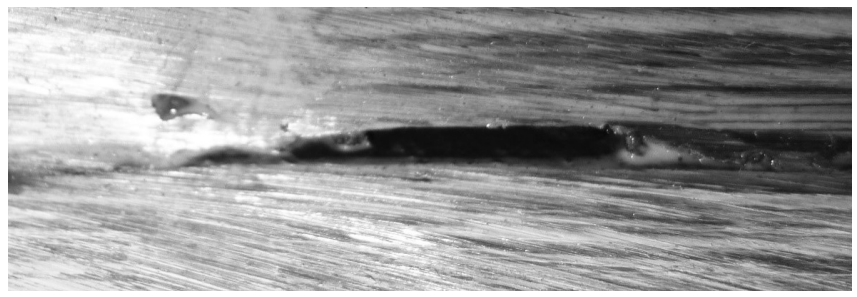

Rys. 12. Niezgodności wykryte podczas badania penetracyjnego (PT) Fig. 12. Imperfections detected during penetration tests (PT)

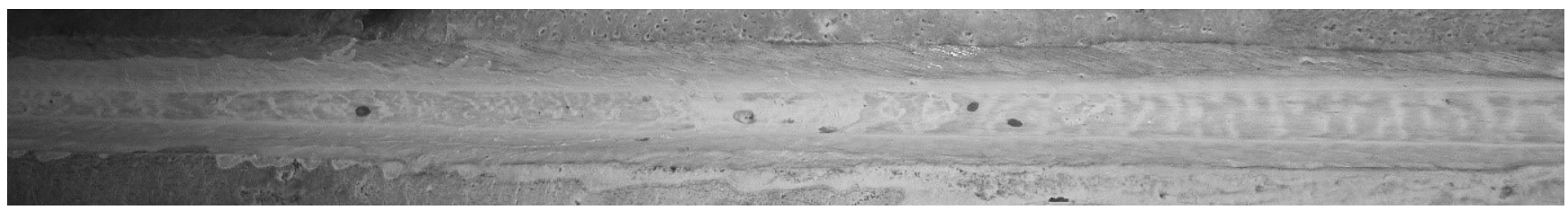

Rys. 10. Badanie penetracyjne po oszlifowaniu warstwy spoiny

Fig. 10. Penetration tests after polishing layer weld 


\section{Nadzór po zakończeniu prac spawalniczych}

Po zakończeniu prac spawalniczych rolą nadzoru jest przygotowanie wykonanych złączy do przeprowadzenia wymaganych badań przez jednostkę badawczą wyznaczoną przez inwestora. W opisywanym przypadku były to $100 \%$ badania VT, PT, UT (rys. 13). Wymagany poziom jakości złączy to "B" wg PN-EN ISO 5817 [8].

Zadaniem nadzoru jest również określenie sposobów naprawy odcinków spoin niespełniających wymagań. Naprawa spoin polegała na wyszlifowaniu miejsca z niezgodno- ściami, sprawdzeniu przy pomocy badania penetracyjnego czy cała nieciągłość została usunięta i wykonaniu zgodnie z opracowaną instrukcją naprawy. W instrukcji powinien zostać przywołany odpowiedni WPS, według którego należy wykonać naprawę. Naprawiane miejsca zostały ponownie przebadane przy pierwotnych wymaganiach.

Obecność nadzoru spawalniczego podczas całego procesu remontu i prowadzenia prac spawalniczych oraz prowadzenie szczegółowych zapisów z prowadzonych prac pozwala na analizy przyczyn powstania niezgodności w wykonanych złączach. Jest to wiedza pozwalająca na uniknięcie podobnych błędów przy kolejnych pracach remontowych.
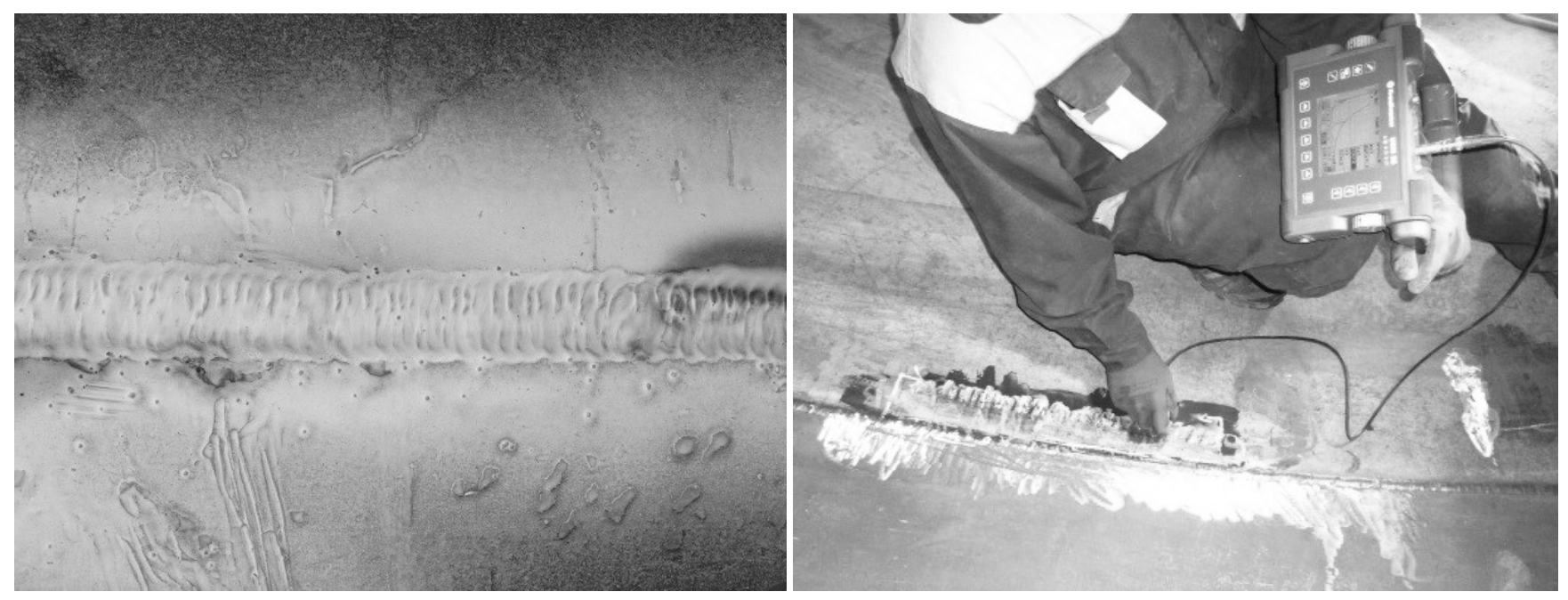

Rys. 13. Wskazania po przeprowadzonych badaniach penetracyjnych oraz badania ultradźwiękowe

Fig. 13. Indications after conducted research after penetration test and ultrasonic tests

\section{Wnioski}

- Prace spawalnicze prowadzone podczas remontów na konstrukcjach przemysłowych wymagają obecności kompetentnego nadzoru spawalniczego.

- Doświadczenie personelu nadzoru umożliwia szybkie podejmowanie decyzji w przypadku wystąpienia odstępstw od założonych wymagań.

- Weryfikacja uprawnień i umiejętności spawaczy, ze szczególnym uwzględnieniem spawaczy firm zewnętrznych, jest warunkiem koniecznym przed dopuszczeniem ich do wykonywania prac spawalniczych.

- Rekrutacja spawaczy „zewnętrznych” musi odbywać się odpowiednio wcześniej przed rozpoczęciem prac spawalniczych.

- Niezmiernie ważnym, dla jakości wykonywanych prac jest przeszkolenie, z zakresu wymagań dla prowadzonych robót, pracowników wykonujących prace przygotowawcze do spawania (monterzy, szlifierze).

- Umiejętność pracowników w zakresie sprawdzenia poprawności przygotowania (wyszlifowania) powierzchni do spawania poprzez badanie PT pozwala na uniknięcie znacznej części niezgodności w wykonywanych złączach.

- Obecność nadzoru spawalniczego i prowadzone przez nadzór zapisy z przebiegu procesu pozwalają na wykrycie przyczyn niezgodności w wykonanych złączach, co umożliwia wprowadzenie działań korygujących i zapobiegawczych podczas prowadzenia podobnych prac.

\section{Literatura}

[1] PN-EN ISO 14731:2008 Nadzorowanie spawania. Zadania i odpowiedzialność

[2] PN-EN ISO 3834-2:2007 Wymagania jakości dotyczące spawania materiałów metalowych - Część 2: Pełne wymagania jakości

[3] Doc. IAB-002-2000/EWF-411: International/European Welding Specialist

[4] Doc. IAB-002-2000/EWF-410: International/European Welding Technologist
[5] Doc. IAB-002-2000/EWF-409: International/European Welding Engineer

[6] PN-EN ISO 9601-1:2014 Egzamin kwalifikacyjny spawaczy - Spawanie - Część 1: Stale

[7] PN-EN ISO 5817:2014 Spawanie. Złącza spawane ze stali, niklu, tytanu i ich stopów. Poziomy jakości według niezgodności spawalniczych 